\title{
Measurement of Judicial Poverty
}

\author{
Muhammad Sohail Anwar ${ }^{1}$, Qais Aslam²
}

\begin{abstract}
\end{abstract}
Justice is an important and functional part of the economy and positively influences the economic performance. Injustice would probably upset the poor more as it hurt the rich. This study identifies three major factors, which are the barriers to access to justice for the poor. Theoretically, this study contributes to defining the judicial demission of poverty and how to address it. On the other hand, this study will also help policymakers make and enforce the policies that can reduce the hurdles in access to justice. This study uses AF methodology, which counts different deprivations faced by individual/household, analyzed to identify poor. Primary data is collected from the district and session court Gujranwala through a self-administrative questionnaire. A total of 893 questions were asked from 112 respondents by adopting the weighted poverty measurement method. A weighted average score it is concluded that each of these three barriers contributes about $21 \%$ of the poverty level. This paper shows an overall $63 \%$ judicial poverty level, 1550 respondents were deprived of 2459 questions. This result is 13\% more than 50\% observed in MPI's weighted indicators (Akire, 2016). It is recommended that the topic should be further explored, particularly by the strong community of scholars, economists, and statisticians in Pakistan, by using these areas as a benchmark.

Keywords: Injustice, Financial Barriers, Technical Barriers, Physical Barriers, AF Methodology

The economy's overall performance is the aggregate of performance of all the institutions in that economy; these institutes are established for public welfare. It is argued in the literature that institutions are a fundamental cause of economic performance (Acemoglu, Johnson, \& Robinson, 2005; North \& Thomas, 1973). Judiciary or justice system is an important part of the economy and is considered an essential virtue of institutions, positively influencing economic performance (Kavuri \& Shao, 2017). So, it is necessary for the betterment of society, and the success of the state, the function and access to justice should be easy and available to all. Social Justice, an indispensable feature of institutions, also positively influences economic performance (Aghion \& Durlauf, 2005).

National Integrity System, 2014 concluded that the foundation of a high-performance economy is based on 13 pillars, and the judiciary is ranked third in them. The expeditious justice system plays a key role in the Governance of the state. It is the state's responsibility to provide quick and fair justice to its citizens because it is a single way to provide a remedy for effective persons against the violation of their basic rights. Later on, it was concluded that an economy's performance is based on its judicial system, stronger the judiciary stronger will be economy (Magnuson, Puiszis, Agrimonti, \& Frank, 2014). Justice system is also considered as an indicator of economic performance, weak or lack of administration of justice badly impacts on economic performance (Messick, 1999).

Sen, 1976's concept of capability approach (e.g., education, good health, and freedom) makes poverty a broader concept. It opens the door for researchers to measure and define poverty in different ways. Measurement of poverty in more than one dimension is based on the idea that it does not matter how good the income indicator is. Still, it is incomplete, which leads to an inaccurate estimation of poverty (Santos \& Salvucci, 2017). Further argue that alternative dimensions such as health, educational level, social exclusion, and insecurity are weakly correlated with income or expenditure (Appleton, \& Song 1999).

Poverty cannot be limited to low income and a lack of expenditure only. Still, it should include different dimensions as attributes of poverty, lack of nutrition, education, voice, powerlessness, physical security, health, capacity, and opportunity to improve one's life and justice (access to fundamental rights) (Klugman, 2010). Several efforts have been considered to reduce the poverty in Pakistan, these efforts have not shown fruitful outcomes, and poverty still holds (Amjad \& Kemal, 1997). According to the report on multi-dimensional poverty, nearly 39 percent of Pakistanis fall in poverty (Akire, 2016). In an ordinary word, deprivation in human wellbeing is known as poverty, (Sen, 1976).

\section{Dimensions of Poverty}

The most traditional method to measure poverty is the Income Approach, based on thinking that income provides money to satisfy and fulfill human needs (Scott 2002). There is a flaw in considering income as a measure of poverty because the assumption of holding equal access to income is not applicable. To resolve this issue, researchers used different indices that add or substitute for income data. These dimensions or attributes include life expectancy, height, weight, caloric intake, formal education, literacy, employment, quality of housing, access to services 'literacy, health, provision of public goods, and income, to name a few. A Development report on poverty identifies four dimensions of poverty: income-poverty, health and education, vulnerability, and voice-lessness (United Nations, 2012).

${ }^{12}$ UCP Business School, Faculty of Management of Studies, UCP, Lahore. Corresponding author Email: qais@ucp.edu.pk 
To draw the full multi-dimensional picture of poverty, keep the measurement approach as broad as possible (Laderchi1997). Consequently, the poverty measurement field is littered with various measures, each assessing a particular dimension of poverty and has its impact and consequences

\section{Justice or Judicial Poverty}

Plato first pointed out the question of justice in his book, The Republic. Plato was not looking at the world in the smaller legal sense. Still, in this book, in its wider economic and social context of economic justice, his focus was on economic justice, which is in modern times, another name of relative poverty (Plato). Inequitable distribution of wealth and opportunities cannot be dealt with without looking at its smaller world legal system. The contention is that there cannot be economic justice if there is no legal protection for the poor.

Injustice is also an attribute of poverty when people have no access to justice, unable to protect their fundamental rights. Government institutes fail to compensate them against violation of their rights, and state institutes lose their control on implementing their rules. Access to justice plays a crucial role in all parts of the above equation; exclusion from the protection provided by law denies them to improve their right (Soros \& Abed, 2012).

The rule of law provides and ensures the fundamental liberties of individuals. The judicial poverty has other components like the right to protect a person, and property fall in Civil law, the safety of business matter in commercial law, social law deals with workers protection and criminal law punishes criminals of serious offenses. These are all interrelated and to overcome the judicial poverty enforcement of these laws is crucial (Truche, 2005).

\section{Indicators of Judicial Poverty}

In the traditional poverty measurement method, the Poverty Line is considered a benchmark to decide inadequately or not: is not an accurate representation of the poverty level in the economy. However, up to some extent, some basic needs can be met or fulfilled by financial sources, and financially poor cannot get access to these needs. Economic poverty deprives the poor of basic needs, but it becomes worse when there is an un-equitable justice system in the country. Here are some factors that prevent the poor from accessing justice, on the other hand, push them into economic poverty.

\section{Financial Barriers}

A person above the poverty line, in violation of his fundamental right, goes to court for remedy and pays some cost in the litigation process. This extra burden utilizes a portion of his income, which ultimately affects his consumption and pushes him below the poverty line. These associated costs are:

$>$ Cost of Legal Assistance

$>$ Legal Fee

$>$ Opportunity Loss

$>$ Corruption

$>$ Transportation Cost

$>$ Guarantee for Bailment

$>$ Telephone Cost

$>$ Other Cost

(Turquet, Ginette, Menon, \& Boyce, 2011-2012).

All these factors are the cause of an increase in economic poverty.

\section{Physical Barriers}

The judicial facilitation centers are situated in urban areas, and this physical distance can be covered only with the help of finance to pay transportation and opportunity cost of traveling. In these circumstances, persons belonging to poverty have to pay double to travel long distances at a high cost and give up his wages as an opportunity cost to engage with the justice system. This double burden raises the problem of a decrease in income and an increase in expenses, causing economic poverty.

$>$ Discriminatory Behavior

$>$ Distance to Court

$>$ Availability of Public transport

Lack of Political Approach

$>$ Lack of information

$>$ Political Involvement

$>$ Pre-trial Detention

\section{Technical Barriers}

Systematic problems in the administration of justice, impact on the judicial institution's performance, and harshly impact people living in poverty, create irritation during the justice chain.

$>$ Strikes in Court

$>$ Fear of Reprisal

$>$ Lack of Legal Standing

$>$ Lack of Legal Identity

$>$ Social Dependence

$>$ Excessive Delay

$>\quad$ Illiteracy and Language Problem

\section{Statement of the problem}

A well-established process of judicial administration guarantees the protection of fundamental human rights and the rule of law. In an ideal situation, if the rights of a person are violated in civil or criminal ways, then he can quickly receive the remedy against this violation. For this purpose, the Constitution of Pakistan established the hierarchy of Judicial Courts. Local Magistrate (Tehsil Level), Session Courts (district level), Higher Courts (Provincial Level), and Supreme Courts (Pakistan Level) to provide easy and quick justice to the public (Tereence 2012).

But statistics show that still a lot of people have not accessed the justice system. Many of them do not go to register their claims for many reasons like (lack of awareness, cost of litigation, and availability of resources). Those who reported their claim, have to bear the extra financial cost, wastage of time, complicated process, excessive delay in the litigation preceding, and huge judicial backlog. So, access to justice was neither speedy nor easy for the poor. At Pakistan level, about to 2 Million cases are still pending in all courts, out which 1.2 Million pending in Only Districts Courts of Punjab (Law and Justice Commission of Pakistan, 2014) It is the right of persons, whether rich or poor, to get access to justice. Still, in the presence of an inadequate justice system, there is discrimination among persons regarding protecting their fundamental rights. This study's primary aim is to highlight the justice dimension of poverty in the Gujranwala Division of Pakistan and elaborate on the main hurdles in the justice system. The literature shows that peoples living in poverty cannot access justice due to these hurdles. This research will emphasize judicial/justice poverty. Elimination of extreme poverty is possible when access to rights (Social, Economic, Cultural, Civil, and 
Political) is accessible and approachable. Access to justice plays a significant role in the protection and promotion of the above rights. Lack of Justice loses the opportunity for persons to claim against their fundamental rights (United Nations, 2012). According to the stated objective of the research, this study will answer the following questions.

\section{Research questions}

$>$ How to measure the administration of justice, and what are the factors of Justice poverty in Pakistan?

$>$ How justice poverty is a cause of economic poverty and pushes the poor into more poverty?

\section{Research objectives}

Lack of Access to the judiciary process, violation of numerous rights, negatively impacts the human wellbeing and performance of the state. Usually, the framework of a legal system designed by highly educated and invoking technical jargon often fails to account for and recognize for capacities and experiences. In this scenario, people living in poverty cannot get access to services. Especially access to justice is a big problem for poor communities; they have to face many hurdles to seek legal redress in judiciary processes. Based on the above factors, this research identifies the barriers in access to justice for people living in poverty. As if there is no equal opportunity to get access to justice, the poor will further fall into more poverty.

\section{Significance of the study}

A healthy Judicial system is necessary for the development and growth of the economy. Violation of fundamental rights has a negative impact on the growth and Governance of the economy. The Government always plans and take the initiative to eliminate discrimination among individuals in society. This study identifies the significanthurdles in accessing to justice system for the protection of fundamental rights. Theoretically, it contributes toward defining the justice demission of poverty and how to address it.

On the other hand, this study will help policymakers to make and enforce the policies which can reduce the hurdles in access to justice. This study is at the grass-root level and recommends a bottom-up and self-defined approach to eliminate justice poverty. In a formal judicial system, the extra financial burden in getting access to courts pushes the poor into more poverty. This factor usually is not considered by economists to measure poverty. This research will help the economist to take into consideration these factors of poverty.

\section{Limitations of the study}

This study is the initial step in measuring justice poverty as a cause of economic poverty. However, it is the base for future researchers to research remedies to solve the problems and make it possible to prevent judicial poor from falling into economic poverty.

\section{Review of Literature}

In this section, historical work related to the study's research question and objective will be summarized. This will be arranged as literature related to poverty and justice poverty, its definition and measurement, factors causing justice poverty, and hurdles in access to justice for the poor's.

\section{Causes of justice poverty}

Sen. 1976, in his concept of the capability approach, pointed out the deprivation in necessary capabilities as a measure of poverty. This research will emphasize judicial or justice poverty, as elimination of extreme poverty is possible when access to rights like Social, Economic, Cultural, Civil, and Political is accessible and approachable. Lack of Justice loses the opportunity for persons to claim the violation of their fundamental rights (United Nations, 2012). When poor people have no access to justice, unable to protect their fundamental rights, government institutes fail to compensate them against any violation of their rights. In the human right perspective, poverty is the human condition of deprivation of choices, security, resources, power of enjoyment, an adequate standard of living, other civil, economic, political, cultural, and social rights (Carmona, 2012).

Access to justice plays a crucial role in all parts of human aspects (Soros \& Abed, 2012). Access to justice and protection of fundamental rights are the factors used to overcome the judicial poverty, enforcement of these laws is crucial (Truche, 2005). There are certain factors which work as barriers in the process of access to justice, it is necessary to provide a quick and expeditious justice these barriers should be removed. This study will divide these barriers into three categories, called financial, physical, and technical obstacles.

The existence of judicial facilitation centers is situated in urban areas; this physical distance can be covered only with finance to pay transportation and opportunity cost of traveling, which is a cause of economic poverty. In this situation, if they have to go to court for the administration of justice, there are some direct and indirect costs in the process of administration of justice. These costs must be paid in initiating the judicial process for seeking a remedy against the violation of fundamental rights. In civil and criminal matters the cost of legal advice, administrative fee, and related collateral cost, guarantee for bail procedure, transportation cost, telephone cost, involvement of corruption, (United Nation, 2012) (International, 2007) Stamp duties, transportation cost, are causes of economic poverty.

The judicial institutions are situated in urban areas, and primarily the appeal courts are located in capital cities far from the rural and remote areas. When a person has to go for a remedy, he has to go to these institutions, and such traveling also involves a sum of money and other associated costs. To face many physical barriers like al Barriers include Physical Distance to Courts(Chakma, 2012), (The State of Juvenile Justice in Himachal Pradesh, 2012). On the other hand, political involvement in administrative institutes provides a hurdle for those who have no political approach, The poor lack of political approach, and lack of information, inadequate legal framework, social and cultural constraints, discrimination against poor, fear of reprisal and sanction system (Foundation, 2012) .economic dependency and subordinate social Guardian (Watch, 2008). More social strata (Dalits, 2011),(International, 2007), pre-trial detention (Foundation, 2012)exploitation from happening of unjust outcome especially who are the victim of domestic violence (Turquet, Ginette, Menon, \& Boyce, 2011-2012). Prejudicial perception 
about inadequate and Discriminatory behavior with poor also a hurdle in the litigation process (Sen, 1983).s

Turquet, Ginette, Menon, \& Boyce, 2011-2012 show that the justice system's design and operation create a barrier at all stages for the poor. There are some complicated parameters and designed a prescribed procedure for filing a suit in criminal and civil courts. This procedure creates some technical requirements which are not easy to fulfill by the poor. These technical barriers include a lack of knowledge of the judicial process (Combrinck \& Wakefield, 2009) (Hoctor, 2012). Legal status in terms of registration certificates is also a problem for putting a claim in courts (World Drug Report, 2001). A large portion of newborn children is not registered. A report shows that more than 50 million births are not registered every year (UNICEF, 2005; UNICEF, 2010) and Excessive Delay (Watch, 2008).

Language problem for illiterate persons also creates a problem in the litigation process, as the legal procedure is communicated in a prescribed language which is not easily understandable for illiterate (Combrinck \& Wakefield, 2009). International human rights law provides that Individuals facing a criminal charge can freely interpret (Turquet, Ginette, Menon, \& Boyce, 2011-2012). Still, this facility is unavailable, limited, and only offered to persons knowing a foreign language. When the poor are unable to pursue justice remedies, it will increase vulnerability to poverty and further hampers the ability to use the justice system. Only one way to defeat poverty is equal access to Justice (Soros \& Abed, 2012). Only one way to defeat the poverty is equal access to Justice (Soros \& Abed, 2012), (Turquet, Ginette, Menon, \& Boyce, 20112012) (Sen, Poor, Relatively Speaking, 1983) (Turquet, Ginette, Menon, \& Boyce, 2011-2012) (Dalits, 2011).

These entire dimensions are measured by the Alkire Foster Methodology approach, which provides equal weighted to each dimension and indicators. A household is scored one if deprived and 0 otherwise. A person is declared as poor if he deprives as more than $33 \%$.

\section{Hypothesis}

The study's working hypothesis is to identify social justice is also a fundamental cause of economic development. Based on abovediscussed literature following hypothesis can be developed as under:

Hypothesis 1: The extra financial burden in the administration of justice positively and significantly predicts the degree of Judicial Poverty.

Hypothesis 2: The involvement of physical hurdles in the process of judicial trial process positively and significantly contributes to Judicial Poverty.

Hypothesis 3: Technicalities in filling a remedy claim in court are hurdles in the administration of justice.

Hypothesis 4: The degree of Judicial Poverty positively and significantly contributes to the degree of Overall MultiDimensional Poverty level in selected districts of Punjab.

Note: All have a Null Hypothesis.

\section{Methodology}

When poverty profile is prepared, or poverty is estimated, it is essential to determine the determinants of poverty in Pakistan. The Methodology used in this study is named as AF methodology, developed by OPHI's (Oxford Poverty Human Index) Sabina Alkire and James Foster in 2010, building on the foster-GreerThorbecke poverty measure. It involves counting the different types of deprivation that individual experiences simultaneously to identify who is poor. It is a flexible approach that can be tailored to various situations by selecting different dimensions and indicators of poverty within each dimension and poverty cutoff.

\section{Population of Study}

The target population of this study included the plaintiff in districts of Gujranwala, Session Courts. The unit of analysis in this study will be individuals. Deprivation is one indicator that will be assumed household will be considered poor. The study's sample size will be 112 individuals who have been part of the judicial process at present or in the past. The MPI (Multi-Dimensional Poverty Index) proposed by Alkire and Santo 2010, 2014, will be applied by its methodological application to measure Judicial Poverty (Access to Justice) as a Dimension of poverty.

\section{Data Collection}

Primary data is collected from the district and session court Gujranwala, a self-administrative questionnaire was developed and filled by spending four days in session court. In this research, Judicial Poverty, measured by three indicators considered as independent variables. These independent variables are Financial Barriers, Physical Barriers, and Technical Barriers, each barrier is calculated with the help of its indices. Following are the measures used in this study:

Deprivation Score of each household the deprivation matrix (c) is computed by identifying as inadequate or not. A household deprived in any indicator is called poor otherwise not. Following standard notation, one indicates that a household is deprived in the corresponding indicator, and 0 indicates that the household is not deprived of that indicator.

Headcount Ratio $(H)$ proportion of people who have been identified as multi-dimensionally poor in the population is also called the incidence of multidimensional poverty. $\mathrm{H}=\frac{q}{n}$ where $\mathrm{q}$ is the total number of deprived indicators, and $n$ is the total number of indicators included in the questionnaire.

The intensity of multi-dimensional poverty $(A)$ average share of weighted indicators in which poor people are deprived. This entails adding up the poor's deprivation scores and dividing them by the total number of poor people, also called the breadth of poverty.

$\mathrm{A}=\frac{1}{\mathrm{q}} \sum_{i=1}^{q} \mathrm{c}(\mathrm{k}) \frac{W 1 * H 1+W 2 * H 2+W 3 * H 3}{H 1+H 2+H 3}$

Where $\mathrm{q}$ is the sum of total household member deprived in any indicator, W represents weight in Financial, Physical, and Technical. In contrast, $H$ represents the sum of Financial, Physical, and Technical, respectively.

\subsection{Model of Study}

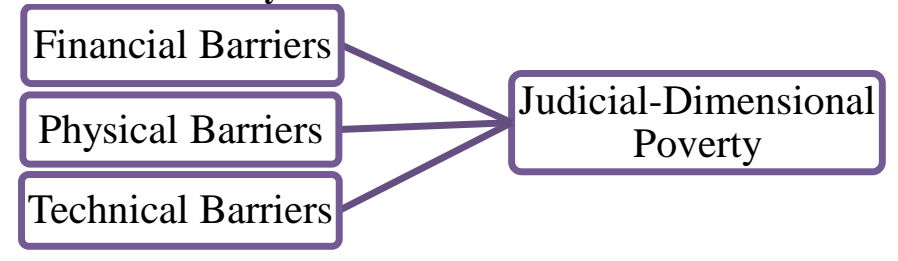


Table 1: Indicators and their Abbreviation along with Deprivation Cutoff.

\begin{tabular}{|c|c|c|}
\hline Indicator & Sym & Deprivation Cutoff \\
\hline Financial Barriers & FB & \\
\hline $\begin{array}{l}\text { Cost of Legal } \\
\text { Assistance }\end{array}$ & $\mathrm{CL}$ & $\begin{array}{l}\text { They are deprived if a person has to pay more } \\
\text { than } 10000 \text { to a lawyer. }\end{array}$ \\
\hline Legal Fee & $\mathrm{LF}$ & $\begin{array}{l}\text { Deprived if more than } 7500 \text { deposit in the court } \\
\text { as initiating the case. }\end{array}$ \\
\hline Opportunity Loss & OL & $\begin{array}{l}\text { They are deprived if a person has to out of his } \\
\text { job without payment. }\end{array}$ \\
\hline Corruption & $\mathrm{C}$ & $\begin{array}{l}\text { They were deprived if an amount of } 500 \text { paid } \\
\text { on each hearing day as bribery. }\end{array}$ \\
\hline Transportation Cost & TV & $\begin{array}{l}\text { They were deprived of more than } 500 \text { charges } \\
\text { that were born in court day as traveling costs. }\end{array}$ \\
\hline $\begin{array}{l}\text { Guaranty for } \\
\text { Bailment }\end{array}$ & GB & $\begin{array}{l}\text { He is deprived if he has to face the problem for } \\
\text { a bailment guarantee. }\end{array}$ \\
\hline Telephone Cost & $\mathrm{TC}$ & $\begin{array}{l}\text { They are deprived if a minimum charge of } \\
\text { court day } 100 \text { is consumed on mobile. }\end{array}$ \\
\hline Other Cost & $\mathrm{OC}$ & $\begin{array}{l}\text { Deprived if more than } 200 \text { paid other than } \\
\text { above mention expenses. }\end{array}$ \\
\hline Physical Barriers & FB & \\
\hline $\begin{array}{l}\text { Discrimination of } \\
\text { Behavior }\end{array}$ & DB & $\begin{array}{l}\text { liscrimination } \\
\text { es. }\end{array}$ \\
\hline Distance to Court & DC & $\begin{array}{l}\text { They are deprived if court distance is greater } \\
\text { than } 15 \mathrm{KM} \text {. }\end{array}$ \\
\hline $\begin{array}{l}\text { Availability of } \\
\text { Vehicle }\end{array}$ & AV & $\begin{array}{l}\text { They are deprived if not possessed personal } \\
\text { conveyance, even a bike. }\end{array}$ \\
\hline $\begin{array}{l}\text { Lack of political } \\
\text { approach }\end{array}$ & LP & $\begin{array}{l}\text { They are deprived if not accessed to a political } \\
\text { party member. }\end{array}$ \\
\hline Lack of information & LI & $\begin{array}{l}\text { It deprived if misguided due to a lack of } \\
\text { information. }\end{array}$ \\
\hline $\begin{array}{l}\text { Political } \\
\text { Involvement }\end{array}$ & PI & $\begin{array}{l}\text { They are deprived if threatened by political } \\
\text { pressure. }\end{array}$ \\
\hline Pre-trial Detention & PD & $\begin{array}{l}\text { They are deprived if retained in pre-trial } \\
\text { detention form more than or equal to } 1 \text { month. }\end{array}$ \\
\hline Technical Barriers & TB & \\
\hline Strikes in Courts & $\mathrm{SC}$ & $\begin{array}{l}\text { They were deprived if the visit to court } \\
\text { remained useless due to strikes or other } \\
\text { uncertainty. }\end{array}$ \\
\hline Fear of Reprisal & FR & $\begin{array}{l}\text { They are deprived if fear of reprisal or } \\
\text { happening of an undue event. }\end{array}$ \\
\hline $\begin{array}{l}\text { Lack of Legal } \\
\text { standing }\end{array}$ & LS & $\begin{array}{l}\text { He is deprived if he has not received a suitable } \\
\text { remedy. }\end{array}$ \\
\hline $\begin{array}{l}\text { Lack of Legal } \\
\text { Identity }\end{array}$ & LI & $\begin{array}{l}\text { He is deprived if he has a problem due to } \\
\text { registration of birth due to minority or } \\
\text { disability. }\end{array}$ \\
\hline Social Dependence & SD & $\begin{array}{l}\text { They are deprived if unable to decide the } \\
\text { judicial process. }\end{array}$ \\
\hline Excessive Delay & ED & $\begin{array}{l}\text { They are deprived if the court trial continues } \\
\text { for more than two years. }\end{array}$ \\
\hline $\begin{array}{l}\text { Illiteracy and } \\
\text { Language Problem }\end{array}$ & LP & $\begin{array}{l}\text { He is deprived if he has less than ten years of } \\
\text { school education. }\end{array}$ \\
\hline
\end{tabular}

\section{Discussion and Findings}

This chapter provides a descriptive summary of the data collected for this research paper. The analysis of this paper is conducted in two steps. In the first step, results are presented as barrier wise. In this research, three barriers or components are used to melsure institutional performance or judicial poverty, these are named Financial, Physical and Technical barriers. Table 2 shows the result summary regarding financial Barriers, in which a total of 112 respondents were asked overall 893 questions about deprivation or non-deprivation. Out of these, 533 respondents were deprived according to unit criteria, which declare a person poor if deprived of any one dimension. This criterion has been objected due to providing a high level of poverty, which is $60 \%$ poor. To resolve this objection, the weighted criteria are applied, which adjusted the deprivation for assigned weights. Here the weight of $1 / 3$ is applied to each of Financial, Physical, and Technical barriers. By adopting the weighted method of poverty measurement, it has the poverty level due to financial Barriers is reduced to $22 \%$. However, when discussing each indicator, the alarming position is the $100 \%$ deprivation in CL, and OC represents the Cost of Legal Assistance and Other costs. This high position shows that all persons involved in the judicial process have to bear at least Rs.5000 as the cost of legal assistance, and on the day of case hearing, they have to bear Rs.200 extra per day. These expenses are a heavy financial burden, especially for the poor.

Table 3 shows the result summary of Physical Barriers. A total of 112 respondents were asked overall 784 Out of these 525 (67\% level of poverty) respondents were deprived according to unit criteria, and this result changed to $21 \%$ by using a weighted average index. However, when discussing each indicator, the maximum poverty level is observed due to Lack of Information and Political Involvement $79 \%$ and $74 \%$, respectively. These percentages show that peoples are in judicial poverty due to a lack of information and political involvement in pressure.

Table 4 shows the result summary concerning Technical Barriers faced by the poor in the judicial process. A total of 112 respondents were asked overall 782 indicators of poverty or deprivation, Out of which 492 (63\% level of poverty) respondents were deprived according to unit criteria and $21 \%$ by using a weighted average index. However, the maximum poverty level $87 \%$ poverty is the excessive delay, which means that the trial process is lengthy and continued for more than two years. The second cause of judicial poverty $75 \%$ of deprivation is due to technical constraints is Lack of Legal standing, which means the person involved in the judicial trial is unhappy or not satisfied with the judicial process or not received a proper remedy. The summary of results is presented in Table 5, which shows that 2459 questions were asked from all respondents, out of which $1550(63 \%)$ response about the existence of deprivation. The maximum poverty level $67 \%$ is observed in Physical constraints, which shows that courts are situated far from their place of residence, and the trial period is prolonged for more than two years. The maximum level is not much differentiated from others, as $63 \%$ observed in technical Constraints while $60 \%$ in financial.

\section{Concluding Remarks}

Institution literature shows that institutions' performance measures economic performance (North, \& Thomas, 1973). Acemoglu, Johnson, \& Robinson, 2005, find out that strong Institutional are the cause of long-run economic growth. Handbook of economic growth, 1, 385-472.) among the institutions in a state judiciary is considered most important. At present, in Pakistan and at the international level, efforts have been made to overcome incomebased poverty. The governments have slightly achieved this milestone, but now it is required to focus on social situations using the Multidimensional Poverty Index. Thus, by using the Alkire Foster methodology of MPI, this paper will be able to highlight the hurdles faced by the poor in the process of administration of justice. This paper's findings present an alarming position that a sample size of 112 respondents from Gujranwala district courts 
was asked about a total of 2459 questions about deprivation. To be identified as poor by the MPI, a minimum of $33 \%$ deprivation score is required (Alkire, Sabina; Foster, James, 2008). This paper shows an overall $63 \%$ judicial poverty level, 1550 respondents were deprived out of 2459 questions. This result is $13 \%$ more as compared to $50 \%$ observed in MPI's weighted indicators(Akire, 2016)

Deprivation in indicators shows a $100 \%$ score in the Cost of Legal assistance and Other Cost beards during the judicial trial. The second most deprived indicator is observed Excessive Delay that shows the trial period is consists of more than two years period. While the states and international laws provide that justice delayed is justice denied (Khan, 2015). The hypothesis presented in this paper is that social justice is also a fundamental determinant of economic growth as well as wellbeing. This argument rests on the notion that justice impacts on different factors or determinants.

\section{Promote future research}

To understand the particular factors and policies which can be beneficial for the reduction in poverty, it is recommended that further research be undertaken, particularly by the substantial community of scholars, economists, and statisticians in Pakistan. This will bring to light specific districts that have successfully reduced multi-dimensional poverty in the shortest space of time, thereby allowing other communities to replicate policies using these areas as a benchmark.

\section{Appendixes}

Table 2: Financial Barriers, along with their Indicators, Abbreviation, and Deprivation Cutoff.

\begin{tabular}{llllllll}
\hline $\begin{array}{l}\text { Symb } \\
\text { ol }\end{array}$ & $\begin{array}{l}\text { Deprive } \\
\text { d }\end{array}$ & $\begin{array}{l}\text { Percenta } \\
\text { ge } \\
\text { Deprived }\end{array}$ & $\begin{array}{l}\text { Weighte } \\
\mathbf{d} \text { \% } \\
\text { Deprive } \\
\text { d }\end{array}$ & $\begin{array}{l}\text { Not } \\
\text { Deprived }\end{array}$ & $\begin{array}{l}\text { Percenta } \\
\text { ge Not } \\
\text { Deprived }\end{array}$ & $\begin{array}{l}\text { Weighte } \\
\text { d \% } \\
\text { Not } \\
\text { Deprive } \\
\text { d }\end{array}$ & $\begin{array}{l}\text { Total } \\
\text { Sampl } \\
\text { e }\end{array}$ \\
\hline CL & 112 & 1.00 & 0.04 & 0.00 & 0.00 & 0.00 & 112 \\
LF & 49 & 0.44 & 0.02 & 63.00 & 0.56 & 0.02 & 112 \\
OL & 33 & 0.30 & 0.01 & 78.00 & 0.70 & 0.03 & 111 \\
C & 66 & 0.59 & 0.02 & 46.00 & 0.41 & 0.02 & 112 \\
TV & 53 & 0.48 & 0.02 & 58.00 & 0.52 & 0.02 & 111 \\
GB & 53 & 0.48 & 0.02 & 58.00 & 0.52 & 0.02 & 111 \\
TC & 55 & 0.49 & 0.02 & 57.00 & 0.51 & 0.02 & 112 \\
OC & 112 & 1.00 & 0.04 & 0.00 & 0.00 & 0.00 & 112 \\
Total & $\mathbf{5 3 3}$ & $\mathbf{0 . 6 0}$ & $\mathbf{0 . 2 0}$ & $\mathbf{3 6 0}$ & $\mathbf{3 . 2 3}$ & $\mathbf{0 . 1 3}$ & $\mathbf{8 9 3}$ \\
\hline
\end{tabular}

Table 3: Physical Barriers, along with their Indicators, Abbreviation, and Deprivation Cutoff.

\begin{tabular}{llllllll}
\hline $\begin{array}{l}\text { Symb } \\
\text { ol }\end{array}$ & $\begin{array}{l}\text { Deprive } \\
\text { d }\end{array}$ & $\begin{array}{l}\text { Percenta } \\
\text { ge } \\
\text { Deprived }\end{array}$ & $\begin{array}{l}\text { Weighte } \\
\text { d \% } \\
\text { Deprive } \\
\text { d }\end{array}$ & $\begin{array}{l}\text { Not } \\
\text { Deprived }\end{array}$ & $\begin{array}{l}\text { Percenta } \\
\text { ge Not } \\
\text { Deprived }\end{array}$ & $\begin{array}{l}\text { Weighte } \\
\text { d \% } \\
\text { Not } \\
\text { Deprive } \\
\text { d }\end{array}$ & $\begin{array}{l}\text { Total } \\
\text { Sampl } \\
\text { e }\end{array}$ \\
\hline DB & 72 & 0.64 & 0.03 & 40.00 & 0.36 & 0.02 & 112 \\
DC & 81 & 0.72 & 0.03 & 31.00 & 0.28 & 0.01 & 112 \\
AV & 71 & 0.63 & 0.03 & 41.00 & 0.37 & 0.02 & 112 \\
LP & 67 & 0.60 & 0.03 & 45.00 & 0.40 & 0.02 & 112 \\
LI & 89 & 0.79 & 0.04 & 23.00 & 0.21 & 0.01 & 112 \\
PI & 83 & 0.74 & 0.04 & 29.00 & 0.26 & 0.01 & 112 \\
PD & 62 & 0.55 & 0.03 & 50.00 & 0.45 & 0.02 & 112 \\
Total & $\mathbf{5 2 5}$ & $\mathbf{0 . 6 7}$ & $\mathbf{0 . 2 2}$ & $\mathbf{2 5 9 . 0 0}$ & $\mathbf{2 . 3 1}$ & $\mathbf{0 . 1 1}$ & $\mathbf{7 8 4}$ \\
\hline
\end{tabular}

Table 4: Technical Barriers, along with their Indicators, Abbreviation, and Deprivation Cutoff.

\begin{tabular}{llllllll}
\hline $\begin{array}{l}\text { Symb } \\
\text { ol }\end{array}$ & $\begin{array}{l}\text { Deprive } \\
\mathbf{d}\end{array}$ & $\begin{array}{l}\text { Percenta } \\
\text { ge } \\
\text { Deprived }\end{array}$ & $\begin{array}{l}\text { Weighte } \\
\mathbf{d} \% \\
\text { Deprive } \\
\text { d }\end{array}$ & $\begin{array}{l}\text { Not } \\
\text { Deprived }\end{array}$ & $\begin{array}{l}\text { Percenta } \\
\text { ge Not } \\
\text { Deprived }\end{array}$ & $\begin{array}{l}\text { Weighte } \\
\text { d \% } \\
\text { Not } \\
\text { Deprive } \\
\text { d }\end{array}$ & $\begin{array}{l}\text { Total } \\
\text { Sampl } \\
\text { e }\end{array}$ \\
\hline SC & 70 & 0.63 & 0.03 & 42.00 & 0.38 & 0.02 & 112 \\
FR & 68 & 0.61 & 0.03 & 44.00 & 0.39 & 0.02 & 112 \\
LS & 84 & 0.75 & 0.04 & 28.00 & 0.25 & 0.01 & 112 \\
LI & 49 & 0.44 & 0.02 & 62.00 & 0.56 & 0.03 & 111 \\
SD & 47 & 0.42 & 0.02 & 64.00 & 0.58 & 0.03 & 111 \\
ED & 97 & 0.87 & 0.04 & 15.00 & 0.13 & 0.01 & 112 \\
LP & 77 & 0.69 & 0.03 & 35.00 & 0.31 & 0.01 & 112
\end{tabular}

\begin{tabular}{|c|c|c|c|c|c|c|c|}
\hline Total & 492 & 0.63 & 0.21 & 290.00 & 2.60 & 0.12 & 782 \\
\hline \multicolumn{8}{|c|}{ Table 5: Summery of overall Results. } \\
\hline $\begin{array}{l}\text { Indicato } \\
\mathbf{r}\end{array}$ & $\begin{array}{l}\text { Depriv } \\
\text { ed }\end{array}$ & $\begin{array}{l}\text { Percenta } \\
\text { ge } \\
\text { Deprived }\end{array}$ & $\begin{array}{l}\text { Weight } \\
\text { ed \% } \\
\text { Deprive } \\
\text { d }\end{array}$ & $\begin{array}{l}\text { Not } \\
\text { Deprived }\end{array}$ & $\begin{array}{l}\text { Percenta } \\
\text { ge Not } \\
\text { Deprived }\end{array}$ & $\begin{array}{l}\text { Weight } \\
\text { ed \% } \\
\text { Not } \\
\text { Deprive } \\
\text { d }\end{array}$ & $\begin{array}{l}\text { Total } \\
\text { Samp } \\
\text { le }\end{array}$ \\
\hline $\begin{array}{l}\text { Financial } \\
\text { ly } \\
\text { Deprived }\end{array}$ & 533 & 0.60 & 0.20 & 360.00 & 3.23 & 0.13 & 893 \\
\hline $\begin{array}{l}\text { Physicall } \\
\text { y } \\
\text { Deprived }\end{array}$ & 525 & 0.67 & 0.22 & 259.00 & 2.31 & 0.11 & 784 \\
\hline $\begin{array}{l}\text { Technical } \\
\text { ly } \\
\text { Deprived }\end{array}$ & 492 & 0.63 & 0.21 & 290.00 & 2.60 & 0.12 & 782 \\
\hline Total & 1550 & 0.63 & 0.63 & 909 & & & 2459 \\
\hline
\end{tabular}

\section{References}

(2011). Access to Legal Aid in Criminal Justice Systems in Africa.

United nations office on drugs and crime. New York: United Nations.

Acemoglu, D., Johnson, S., \& Robinson, J. A. (2005). Institution as a fundamental cause of long-run (Vol. 1). Cambridge, London: Elsevier.

Aghion, P., \& Durlauf, S. (2005). Handbook of Economic Growth (1 ed., Vol. 1). Washington: Elsevier.

Akire, S. (2016). Multi-dimensional Poverty in Pakistan. Islamabad: Oxford Poverty \& Human Development Initiative.

Ali, I., Saboor, A., Ahmad, S., \& Mustafa. (2010). Identifying the pathways out of poverty: Evidence of exit time poverty estimations in Pakistan. Pakistan Journal of Life and Social Sciences, 8 (1), 24-29.

Alkire, S., Roche, J. M., Seth, S., \& Sumner, A. (2014, November 12). Identifying the poorest people and groups: strategies using the global multidimensional poverty index. Working Paper No. 78,1 (1), p. 30.

Alkire, Sabina. (2016). Multi-dimensional Poverty in Pakistan. Islamabad: Oxford Poverty \& Human Development Initiative.

Alkire, Sabina; Foster, James. (2008, January 17). Counting and multi-dimensional poverty measurement. Working Paper Series, 1(1), p. 33.

Alkire, Sabina; Seth, Suman. (2009, May 18). Measuring multidimensional poverty in India: A new proposal. Working Paper No. $15,1(1)$, p. 51.

Alkire, Santos. (2013, March 01). Measuring acute poverty in the developing world: Robustness and scope of the multidimensional poverty index. World Development, 1(1), pp. $1-48$.

Amjad, R., \& Kemal, A. R. (1997). Macroeconomic policies and their Impact on poverty alleviation in Pakistan. The Pakistan Development Review, 36 (1), 39-68.

Arif, G. M. (2000). Recent rise in poverty and its implications for poor households in Pakistan. The Pakistan Development Review, 39(4), 1153-1170.

Ballon, P., \& Duclos, J.-Y. (2015, April 12). Multi-dimensional poverty in Sudan and South Sudan. Working Paper No. 93, 1(1), p. 47.

Banteay Srei. (2005). Pathways to Justice: Access to Justice with the Focus on Poor, Women. UNDP.

Barendrecht, M., Mulder, J., \& Giesen, I. (2006, November). How to measure the price and quality of access to justice? 
Battiston, Diego; Cruces, Guillermo; Calva, Luis Felipe Lopez; Lugo, Maria Ana; Santos, Maria Emma. (2009, September 18). Income and beyond: Multi-dimensional poverty in six Latin American countries. Working Paper . 17, 1(1), p. 31.

Carmona, M. S. (2012). Extreme poverty and human rights. Promotion and protection of human rights. United Nations.

Chakma, S. (2012, December). The State of Juvenile Justice in Himachal Pradesh. Retrieved March 17, 2017, from Asian Centre for Human Rights: http://www.achrweb.org/reports/india/.

Cheema, A., Khalid, L., \& Patnam, M. (2008, September). The Geography of poverty: Evidence from Punjab. The Lahore Journal of Economics, 163-188.

Combrinck, H., \& Wakefield, L. (2009). Training for the Police on the Domestic Violence Act. University of the Western Cape, Community Law Centre. Bellville: Saartjie Baartman Centre for Women and Children.

Dalits. (2011). Office of the High Commissioner for Human Rights. OHCHR-Nepal. Kathmandu, Nepal: United Nations.

Foundation, O. S. (2012). Improving Pretrial Justice: the roles of lawyers and paralegals. Open Society Justice Initiative. New York: Open Society Foundation.

Genn, H., Beinart, S., Finch, S., Korovessis, C., \& Smith, P. (1999). Paths to justice: what people do and think about going to the law (Vol. 1). Portland, USA: HART Publishing.

Hoctor, L. (2012). Women's Access to Justice Identifying the Obstacles \& Need for Change. Geneva: International Commission of Jurists.

International, T. (2007). Global Corruption Report. Berlin: Transparency International.

Kavuri, A. S., \& Shao, H. (2017, March 18). The impact of social justice on economic performance. CAMA, 1(1), pp. 1-32.

Khan, A. N. (2015, 06, 07). Justice delayed is justice denied. Lahore, Punjab, Pakistan. Retrieved March 15, 2018

Klugman, J. (2010). Human Development Report. World Bank, United Nations Development Programme. Washington DC: Palgrave Macmillan.

Law and Justice Commission of Pakistan. (2014). Judicial Statistics of Pakistan. Islamabad: Supreme Court of Pakistan.

Madeleine K. Albright. (2008). Making the Law Work for Everyone. Commission on Legal Empowerment of the Poor. New York: Consolidated Graphics.

Magnuson, E., Puiszis, S., Agrimonti, L., \& Frank, N. (2014). The Economic of Justice. DRI, Economics. Chicago: DRI.

Mahoozi, H. (2015, June 12). Gender and Spatial Disparity of Multi-dimensional Poverty in Iran. Working Paper No. 95, 1(1), p. 28.

Messick, R. (1999). Judicial reform and economic development: a survey of. Washington: Worldbank.

National Integrity System. (2014). Pakistan's National Integrity System Country Report. Transparency International Pakistan.

North, D., \& Thomas, R. (1973). Thomas the rise of the western world. Recherches Économiques de Louvain, 41 (2), 83.

(2012). Not Fair Enough. Making the case for reform of the social welfare appeals system. Dublin: FLAC.
Plato. The Republic (1 ed., Vol. 1). London, Great Britain: Harvard University Press.

Sabina Alkire. (2007, August 12). Development "a misconceived theory can kill”. OPHI Working Paper No. 11, 1 (1), p. 20.

Santos, Karma. (2008, August 10). Multi-dimensional Poverty in Bhutan: Estimates and Policy Implications. Ophi Working Paper No. 14, p. 25.

Santos, R., \& Salvucci, V. (2017). Multi-dimensional poverty and wellbeing in Mozambique. Uni Wider, (p. 233).

Sekaran, U., \& Bougie, R. (2010). Research methods for business: A skill building approach. In U. Sekaran, Research Method for Business (pp. 1-448). John Wiley \& Sons.

Sen, A. (1976). Poverty: An ordinal approach to measurement. Econometrica, 44(2), 219-231.

Sen, A. (2000, June). Social exclusion: concept, application, and scrutiny. Social Development Papers, 1, p. 60.

Sen, Amartya. (1983). Poor, relatively speaking. Oxford Economic Papers, 35(1), pp. 153-169.

Sen, Amartya. (1976). Poverty: An ordinal approach to measurement. Econometrica, 44(2), 219-231.

Soros, G., \& Abed, F. H. (2012, September 26). Rule of law can rid the world of poverty. Retrieved March 16, 2017, from Financial Times: https://www.ft.com/content/f78f8e0a-07cc11e2-8354-00144feabdc0

The State of Juvenile Justice in Himachal Pradesh. (2012, December). Retrieved March 17, 2017, from Asian Centre for Human Rights: http://www.achrweb.org/reports/india/

Truche, P. (2005). Selected Considerations Anchored in the Universal Declaration of Human Rights. In R. V. Puymbroeck (Ed.), Comprehensive Legal. 1, p. 364. Washington, DC: World Bank.

Turquet, L., Ginette, A., Menon, R., \& Boyce, C. (2011-2012). Progress of the World's Women: In Pursuit of Justice. Progress of the World's Women. United Nations.

Udel, D., \& Diller, R. (2007). Access to justice: Opening the courthouse door. New York: Brennan Center for Justice.

UNICEF. (2010, May 25). 51 million: The number of children unregistered at birth is 51 million. Retrieved 03 19, 2017, from UNICEF:

https://www.unicef.org/factoftheweek/index_53718.html

UNICEF. (2005). The 'Rights' start to life: A statistical analysis. UNICEF, Rights Start to Life. UNICEL.

United Nation. (2012). Promotion and protection of human rights: Human rights situations and reports of special rapporteurs and representatives. United NAtion.

United Nations. (2012). Not Fair Enough. Making the case for reform of the social welfare appeals system. Dublin: FLAC.

Watch, H. R. (2008, March). Adults before their time: Children in Saudi Arabia's criminal justice system. Human Rights Watch, 20(1), p. 84.

World Bank. (2016). World Development Report. Washington: World Bank.

(2001). World Drug Report. Oxford University, UNODC. New York: Oxford University Press. 